\title{
Vegans who Run
}

\author{
Ben Agger
}

Body politics has been on the radar at least since feminists noticed that fat is a feminist issue. Earlier, MerleauPonty and Beauvoir contested the Cartesian splitting of mind and body. Their compatriot, Sartre, hung with them at Deux Magots in Paris, where existentialism, stressing personal agency, was born. Even philosophers have to eat.

Susie Orbach (1978) penned Fat is a Feminist Issue at a time when the women's movement was differentiating itself from, although borne of, the male New Left. Feminist theory and practice recognized that the personal is political. The so-called private sphere concealed very public and political matters such as who does housework and childcare, how sexuality is transacted, birth control, career primacy, and the objectification and self-objectification of women's bodies. There is by now a vast literature (e.g., Bordo 1993; Hesse-Biber 1996) on the specific issue of women's weight and self-esteem.

Feminist studies sprang from feminist practice, beginning with Suffrage. Feminist scholarship was always in service of a personal politics, which helped women negotiate various gender troubles, from sexuality to children to dealing with men. The empowering of sixties women led to legal, economic and cultural changes that, together, have shrunk the income gap, left women as the majority of college students, and led to women's participation in politics and sports.

In 1967, Katherine Switzer (2007), who loved to run, crashed the male-only Boston Marathon, leading to Title IX in 1972 and, eventually, to the first women's Olympic marathon in 1984. The race director, Jock Semple, tried unsuccessfully to throw Switzer off the course. (Boston had been completed covertly by a "bandit" runner, Roberta Gibb, in 1966, when she ran the very quick time of 3:21. And Merry Lepper reportedly completed the 1963 Culver City marathon, running unofficially.) The delirious applause awaiting the Olympic winner, Joan Benoit, as she ran into the Los Angeles Coliseum signaled that women had begun to turn their objectified bodies into powerful subjects. Maybe Joanie did not think in these terms, having grown up efficacious in Maine and perhaps not having taken women's studies courses at Bowdoin. Nevertheless, a straight line can be drawn from Switzer, Gibb and Lepper to Benoit (1987) to the massive participation of women today in $5 \mathrm{Ks}$, half marathons, marathons, mud runs, triathlons and nearly every other venue of athletic participation. Showing my age, I marvel at the fact that most of my women college students never knew a world before Title IX. For them, soccer, volleyball, softball and track are unproblematic options.

When Switzer blazed the way for women in sports, Gatorade was two years old. McDonald's had not yet opened a franchise in my hometown of Eugene, Oregon, where the Bill Bowerman-coached Oregon track teams were winning national titles and Olympic medals. Bowerman returned five years earlier from a visit to New Zealand, where he met Arthur Lydiard (Lydiard and Gilmore 1978), the father of modern endurance training theory, about whom I will speak later.

We had not yet become fast-food nation (Schlosser 2012), with rampant body problems, stemming from inactivity, too many sugar and fat calories, processed food, factory farmed vegetables and meat, fried food. The worst of these body problems include heart disease, cancer, diabetes, autoimmune disorders and obesity. We medicalize and commercialize body problems, giving rise to body industries such as mainstream health care, big pharmaceutical companies, gyms, fad diet plans and drugs, cosmetic and bariatric surgery. The "western diet" makes people sick and then they are healed, for profit.

And so, just as patriarchy triggered a feminist politics of the personal, making the private public and political, 
which in turn spurred a feminist paradigm of theory and scholarship, so a fast-food nation has triggered a personal food and body politics. I argue here that this food and exercise practice has generated a new interdisciplinary framework perhaps best called Critical Food and Exercise Studies. Here, I weave the disparate threads of this paradigm, and also argue for an appreciation of endurance veganism as a personal politics tying together food and exercise.

I discuss four literatures that congeal into Critical Food and Exercise Studies: critical food theory (Pollan [2007, 2008], Schlosser, Petrini [2003]), plant-based epidemiology and cardiology (Esselstyn [2008], Ornish [1990], Campbell [Campbell et al. 2006]), running/endurance theory (Lydiard, Bowerman), and running veganism (Jurek [2013], Roll [2012], VanOrden [2013]). Synthesizing the four literatures above, I argue for endurance veganism as a personal politics appropriate to fast-food nation.

\section{| Critical Food Theory}

Pollan, Schlosser, Petrini and Moss address food Fordism in post-WWII America, which has become a global model. From within sociology, Ritzer [(2012) and Glassner (2007) contribute to this perspective, although without the focus on political economy. Schlosser's Fast Food Nation and a series of films and videos, including the cult classics, "Super Size Me," "Forks Over Knives," "King Corn," and "Food, Inc." bring this argument into the mainstream, especially for young people.

Schlosser and Pollan argue that the commodification of protein, fat and carbohydrates produce an abundance of inexpensive calories. Even though the official food pyramid has been replaced by the food plate, somewhat decentering meat, critical food theorists focus on the centrality of meat, dairy products and grains, especially white flour, in the American diet. At issue are (a) factory-like farming and meatpacking, which drive out local independent producers, and (b) the poor nutritional quality of fatty, sugary, meaty foods that produce cravings and dependency. Critical food theorists link these trends to the overall development of capitalism, which is now going global, reflected in the proliferation of McDonald's franchises in the PRC and in other non-western countries.

And so these food theorists link the logic of capital with the disastrous health consequences for consumers of the western fast-food based diet, which produces all sorts of health deficits, such as obesity, metabolic syndrome, heart disease, diabetes and cancer. Schlosser links the rise of fast food with the development of the interstate highway system, both of which have grave environmental consequences. Critical food theory is, in effect, an application of a critique of capitalism to food and farming.

\section{| Plant-Based Epidemiology and Cardiology}

Tony Gonzalez, now playing for the Atlanta Falcons, is arguably the greatest tight end of all time. His teammates have nicknamed him "China Study," for his eating habits. He is nearly a vegan, avoiding most meat and all dairy. China Study is one of the most famous epidemiological studies, tracking the eating habits and patterns of heart disease and cancer among more than 6,000 people in China. Colin Campbell, formerly at Cornell, is the American name often associated with this voluminous study undertaken by American and Chinese health scientists. Campbell and his colleagues find strong correlations between eating meat and illness, inspiring generations of Americans to give up meat and even fish and dairy.

Gonzalez is living proof that one can be healthy and avoid meat and dairy. Tight ends are big, strong and fast. The China study is perhaps the most important inspiration of a plant-based epidemiology and cardiology. "Forks over Knives" explores the methodology and findings of the China study, and also highlights the clinical work of Caldwell Esselstyn, of the Cleveland Clinic. The plot line of the movie is the struggle of two fat and illness-prone guys to lose weight and eat healthier by embarking on a diet of juiced vegetables.

Esselstyn was a general surgeon at the Cleveland Clinic, where heart bypass surgery was pioneered. Esselstyn, who won a gold medal in rowing at the 1956 Olympics, lamented the fact that people's chests were being opened up for heart bypasses, preferring prevention to dangerous and costly surgery. Instead, he took 18 very sick cardiac patients and put them on strict vegan diets (and low doses of statin drugs). Astonishingly, in almost all cases, their 
heart disease was slowed and even reversed, suggesting that the western diet is the cause of much heart diseaseexactly the point made by Campbell and his colleagues.

Dean Ornish, a cardiologist from California, did similar research and came up with the nearly identical conclusion that a vegan diet and exercise could prevent, retard and reverse heart disease. Both Esselstyn and Ornish derive from the pioneering work of Nathan Pritikin, a heart patient himself, who championed low-fat diets in the 1970s and 1980s. Esselstyn's son, Rip (R. Esselstyn 2009), an all-American swimmer at Texas and later a national-caliber triathlete, and now a firefighter in Austin, Texas, has popularized his dad's diet in books and videos. Rip prefers the term "plant-strong" to describe the diets of his firefighter colleagues and many others who went vegan, lost weight and improved their cholesterol and blood-pressure profiles. Perhaps predictably, his branded food is now available at Whole Foods.

\section{| Running/Endurance Theory}

Switzer got American women running, drawing on the legacies of Arthur Lydiard and Bill Bowerman. As noted earlier, Bowerman traveled with his track team and brought home a revolutionary approach to running and training theory, based on the work of Arthur Lydiard. Lydiard first found fame by coaching New Zealand athletes such as Peter Snell to Olympic gold in the half mile and mile using a method of training emphasizing long, steady miles run in order to build an aerobic base, followed by strength and speed work that would sharpen the athlete for races all the way from the half mile to the marathon. Lydiard trained Snell to run marathons, thus providing him a base of cardiac fitness that would enable him to run not only one fast lap (quarter mile) but four or more laps. Before Lydiard, speedy milers such as Roger Bannister and John Landy only ran fast quarter-mile "intervals," for the most part neglecting longer, slower runs that would build endurance. Now, world-class Kenyan, Ethopian and other world athletes use one or another version of Lydiard's pioneering approach to base building followed by sharpening and then peaking. Neo-Lydiardists include Bowerman (Moore 2006), Jack Daniels (2005), Mark Wetmore (Lear 2003), Brad Hudson (2008), the Hanson brothers (Humphrey 2012) and Renato Canova (Davis 2012).

So, how far did Lydiard want his base-building runners to run? Fully 100 or more miles a week, in double daily workouts! Hard and long days would be followed by easy, recovery days, a hard/easy pattern developed by Bowerman at Oregon. But Bowerman brought back to Eugene another very powerful idea, which is, I believe, the real legacy of Lydiard: He exposed Americans to Lydiard's contention that anyone can run a marathon, anyone can become an athlete, if they proceed patiently, developing full aerobic capacity (Bowerman and Harris 1967). Not long after he returned from New Zealand, the streets of Eugene were filled with "joggers," sheer amateurs who ran alongside the elite 'men of Oregon.'

Bowerman helped found Nike, which introduced the Cortez and Waffle trainers and thus nearly single-handedly started the first running revolution during the 1970s and 1980s. By now, at the height of the second running revolution, races have expanded to include women, walkers and people struggling to get into shape and lose weight. Kenneth Cooper (1977), a Dallas cardiologist, converged with Lydiard and Bowerman in his classic self-help treatise, Aerobics, in which he argues that people can achieve substantial fitness by doing half an hour of cardiac work at least three times a week. It is perhaps inevitable that Nike began with running shoes sold out of the back of a VW to serious runners at local races, and emerged as a global corporation that sells expensive apparel to non-athletes.

\section{Running Veganism}

As road running evolved from its early 1970s/1980s edginess-think of Oregon's iconic runner Steve Prefontaine, a rebel without a cause - to a more corporate and commodity version today, with high-fashion gear and for-profit races, rebellious runners moved away from short road races, such as 5 and $10 \mathrm{Ks}$, to off-road trail races that are frequently much longer than 26.2 miles, the marathon distance. Ultra runners are often hippies who live off the grid, subsisting on meager income and the occasional shoe-company contract. The Boulder-based Tony Krupicka comes to mind. Some ultra runners, such as Charlie Engle and Marshall Ulrich (2011), embark on journey runs, from city to city and across whole continents. James Shapiro (1982) chronicled his own solo "transcon" (across the United 
States) in Meditations from the Breakdown Lane: Running Across America. And a Herculean 4,000 mile run across Africa was captured in the stirring movie Running the Sahara. A tamer, off-beat 197-mile relay from Mt. Hood to the Oregon coast is chronicled in the film Hood to Coast.

Scott Jurek, America's greatest ultramarathoner, grew up in the meat-eating wilds of Minnesota and discovered his distance-running talent. Eventually, he shifted to plants and gave up meat and dairy altogether, as he discussed in Eat \& Run. When Jurek went vegan, he became a great runner, and won the fabled Western States 100-miler from Squaw Valley to Auburn, California seven times in a row. Tim VanOrden and Rich Roll are also ultramarathoners who follow a vegan diet. As they abandoned the western diet, and derived life-giving protein, carbs and fat from plants, their performances improved, they became leaner, and they recovered from effort more quickly. They were endurance vegans, supremely fit, Lydiard-trained athletes who reject factory food, fast food, refined food as they strike a balance with nature by running lightly through it. For these runners, running, fueled by a vegan diet, was a form of critique and liberation, a politics of the personal.

A body politics, stressing non-western, plant-based diets and endurance exercise, gives people control over their own health, including their relationship to nature and animals. But it is also playful activity not done for instrumental reasons, such as achieving a certain body mass index (BMI) or getting a promotion. Kant talked of freedom as purposive purposelessness, which is very much the argument made by George Sheehan, a running cardiologist. The philosopher and poet of running, Sheehan (1978) in Running and Being speaks of running, a meaningless activity, as the key to meaning, which is achieved when the mind and body mesh and move fluidly. In my (Agger 2011) writing about bodies and runners, I address the experience of flow, which involves breathing and rhythmic movement (also see Csikszentmihaly 1990).

Vegans who run protest capitalist food, transportation technologies based on the internal combustion engine, the commodification of exercise. They resist alienated labor by spending their own sweet time on the road or trail. Sheehan argued that we are most fully human when we exercise, and now reporters on exercise-brain science such as Chris Bergland (2007) trace this to the production of endorphins, serotonin and endocannabinoids during endurance activity, which produce what he calls bliss. This from a guy who sweated through the cruel 135-mile Badwater run across Death Valley in the summer! I rarely have a runner's high, perhaps because in my running life I teeter on the edge of overtraining. Running blunts anger and alienation, and, matched with a plant-based diet, insulates one against the toxins of the western diet and mainstream medicine, which picks up the pieces. It is difficult to be at cross-purposes with oneself when one runs 35 to 40 miles a week or more.

This is not a jeremiad against meat or dairy. Meat is not just meat; free range is vastly different from factory fed and fattened. Vegans need B-12, which may come in the form of a supplement. Pritikin and the rural Chinese view meat as a condiment. Rigidity derives from dogma. But there is no denying that non-western cultures such as that of the Tarahumara Indians enjoy freedom from disease, longevity and the vitality of their native trail runners. Chris McDougall (2011), who gained entrée to the Tarahumara through mystic-hippie runner Micah True ("Caballa Blanco"), introduces readers in Born toRun to minimally-shod trail running. Ironically, True, on a long run in Utah, died at 58 of cardiac disease. He was running alone in the wilderness he loved. Running doesn't convey immortality, as other running gurus discovered. Jim Fixx (1977), who wrote The Complete Book ofRunning, died, while running, at 52, while George Sheehan died at 78 of prostate cancer, discovered during a routine exam at the Cooper Clinic in Dallas. Bill Rodgers (2013), the draft-avoiding New England marathoner who won many Bostons and New Yorks, is beating back prostate cancer. It does not need to be said that runners are not immortal, but one notices here that heart disease and cancer are inflected by the western diet. A physician who ran, Sheehan felt invulnerable and avoided prostate exams until it was too late.

As soon as one writes the word "runner," one imagines training schedules, shoes, running groups, VO2 max (oxygen uptake) testing_-running reduced to dreary science and consumer goods. One can spend $\$ 1000$ a year on race entry fees if one races a lot. Races dot the bucket lists of many, who abandon the sport once they have the 13.1 sticker on their gasoline cars. By the same token, vegans often seem cultic and Puritanical, and they regard less sturdy souls as morally inferior. Gyms resemble factories with work stations.

Runners, prone to compulsiveness, readily invest their-our!--avocation with metaphysical importance. Meanwhile, our bodies break down. The female athlete's triad syndrome combines eating disorders such as anorexia, osteoporosis and amenorrhea. Some Division-I track teams have both male and female athletes keeping calorie diaries. No one is immune. I rationalize owning a Garmin Forerunner (GPS watch), and I run Veronique Billat's (2013) trendy vVO2 workouts. ('V' doesn't stand for vegan.) It is easy to become too invested.

Running teaches one not to be attached to the inessential. Marcuse (1964) writes of false needs. Running 
vegans are minimalists. Shoes, beans, broccoli and tortillas are a runner's basic needs. Like Shapiro, I am attracted to distance because enduring distance requires one to confront oneself. It is the hard path. Haraki Murakami (2009) writes of this in What I Talk about When I Talk about Running, suggesting a convergence among Zen-oriented runners and the classic 1970s treatment by Pirsig, Zen and the Art of Motorcycle Maintenance.You can't tell yourself lies when the glycogen is nearly gone and you are running on fumes.

My favorite running writer remains Jim Shapiro, who wrote about his transcon and about an earlier six-day goas-you-please race in England. That essay, "Swifts on the Wing," borrowed the metaphor of the swift, a bird which never touches ground. By Shapiro's telling, only the crazy few, committed to distance for its own sake, would run endless laps of a track, piling up 60 or more miles a day for six days. Few in the mainstream media tracked Charlie Engle and Marsh Ulrich's 2008 attempt to set a land speed record across America, captured in their film Running America. One of them couldn't finish and they didn't remain friends, showing that remorseless endurance activities don't guarantee the endurance of relationships.

It is challenging to pierce the thin boundary between personal politics and a more public kind, involving social movements, institutions, power. As the sixties fizzled out and a long siege of reaction set in, connecting Nixon/ Hoover to Reagan/Bush Jr./Rove, former activists grew dispirited and turned toward personal growth, communes and organic farming. Jacoby (1975) lamented a politics (purely) of subjectivity and Lasch (1979) warned of a culture of narcissism. This is tricky, because feminists aptly demonstrated the connection between bedroom and boardroom, body politics and a more public kind.

Marcuse (1969) in Essay on Liberation argued that radical change must pass through, and affect, the self. It must be chosen, desired. But in Counterrevolution and Revolt (1972) he tracked the descent of progressive personal politics of early SDS into the authoritarianism of the Weather Underground. Feminists were perhaps more adept than the male Left at joining personal politics and legislative and political-economic agendas. Endurance veganism is inadequate unless it leads to critiques and transformations of agribusiness, school lunch programs, federal farm subsidies, mainstream nutrition and health care. Perhaps swimming upstream in a carnivorous state, the University of North Texas opened a vegan cafeteria. Courses in aerobic activities, such as running and walking, should be part of every curriculum, from $\mathrm{K}$ to 12 and beyond. Attention deficits are the body's responses to the microphysics of school desks and inactivity as well as the stress produced by hectoring adults. It is a national tragedy that discipline has become pharmacological as we medicate restless young bodies.

Vegans who run have the same problems as the rest of the world, except for meat, dairy, sugar, processed food, heart disease, certain cancers, diabetes, hypertension, and the stressful rat-race of alienated labor. But, as we learned during the sixties and seventies, personal politics matter, even if they are concealed by patriarchs who wanted to keep them invisible and now by big food, medicine and pharma. Food and body politics call forth endurance veganism as a lifestyle and political stance. Critical food and exercise studies track these interesting developments, expanding sociology into exotic realms such as clinical cardiology, nutrition, agricultural political economy and training theory. Sociologists have to eat.

\section{References}

Agger, Ben. 2011. Body Problems: Running and Living Long in a Fast-Food Society. New York: Routledge.

Benoit, Joan (with Sally Baker). 1987. Running Tide. New York: Knopf.

Bergland, Christopher. 2007. The Athlete's Way: Sweat and the Biology of Bliss. New York: St. Martin's.

Billat, Veronique. 2013. http://www.billat.net/

Bordo, Susan. 1993. Unbearable Weight: Feminism, Western Culture and the Body. Berkeley: University of California Press.
Bowerman, William J. and W. E. Harris. 1967. Jogging: A Physical Fitness Program for all Ages. New York: Grosset \& Dunlap.

Campbell, T. Colin, Thomas M. Campbell II, Howard Lyman and John Robbins. 2006. The China Study: The Most Comprehensive Study of Nutrition Ever Conducted And the Startling Implications for Diet, Weight Loss, And Long-term Health. New York: BenBella Books.

Cooper, Kenneth H. 1977. Aerobics. New York: Bantam. 
Csikszentmihaly, Mihaly. 1990. Flow: The Psychology of Optimal Experience. New York: Harper \& Row.

Daniels, Jack. 2005. 2nd ed. Daniels' Running Formula. Champaign, IL: Human Kinetics.

Davis, John. 2012. http://www.runningwritings.com/2012/06/ elite-marathoning-with-renato-canova.html.

Esselstyn, Caldwell.2008. Prevent and Reverse Heart Disease: The Revolutionary, Scientifically Proven Nutrition-Based Cure. New York: Avery Trade.

Esselstyn, Rip. 2009. The Engine 2 Diet: The Texas Firefighter's 28-Day Save-Your-Life Plan that Lowers Cholesterol and Burns Away the Pounds. New York: Wellness Central.

Fixx, Jim E. 1977. The Complete Book of Running. New York: Random House.

Glassner, Barry. 2007. The Gospel of Food: Everything you Think you Know about Food is Wrong. New York: Ecco.

Hesse-Biber, Sharlene Nagy. 1996. Am I Thin Enough Yet? The Cult of Thinness and the Commercialization of Identity. New York: Oxford University Press.

Hudson, Brad (with Matt Fitzgerald). 2008. Run Faster from the $5 \mathrm{~K}$ to the Marathon: How to Be Your Own Best Coach. New York: Broadway Books.

Humphrey, Luke (with Keith and Kevin Hanson). 2012. Hansons Marathon Method: A Renegade Path to Your Fastest Marathon. Boulder: VeloPress.

Jacoby, Russell. 1975. Social Amnesia: A Critique of Conformist Psychology from Adler to Laing. Boston: Beacon.

Jurek, Scott. 2013. Eat \& Run: My Unlikely Journey to Marathon Greatness. Boston: Houghton Mifflin Harcourt.

Lasch, Christopher, 1979. The Culture of Narcissism: American Life in an Age of Diminishing Expectations. New York: Norton.

Lear, Chris. 2003. Running with the Buffaloes: A Season Inside with Mark Wetmore, Adam Goucher and the University of Colorado Men's Cross-Country Team. Guilford, Conn.: Lyons Press.

Lydiard, Arthur and Garth Gilmour. 1978. Running the Lydiard Way. Mountain View, CA.: World.

Marcuse, Herbert. 1964. One-Dimensional Man. Boston: Beacon.

----.1969. An Essay on Liberation. Boston: Beacon.

-----1972. Counterrevolution and Revolt. Boston: Beacon.

McDougall, Christopher. 2011. Born to Run: A Hidden Tribe, Superathletes, and the Greatest Race the World has Never Seen. New York: Vintage.
Moore, Kenny. 2006*. **Bowerman and the Men of Oregon: The Story of Oregon's Legendary Coach and Nike's Co-founder*. Emmaus, PA: Rodale.

Moss, Michael. 2013. Salt Sugar Fat: How the Food Giants Hooked Us. New York: Random House.

Murakami, Haraki. 2009. What I Talk about When I Talk about Running. New York: Vintage.

Orbach, Susie. 1978. Fat is a Feminist Issue: The Anti-Diet Guide to Permanent Weight Loss. New York: Paddington.

Ornish, Dean.1990. Dr. Dean Ornish's Program for Reversing Heart Disease: The Only System Scientifically Proven to Reverse Heart Disease Without Drugs or Surgery. New York: Random House.

Petrini, Carlos. 2003. Slow Food: The Case for Taste. New York: Columbia University Press.

Pirsig, Robert M. 1974. Zen and the Art of Motorcycle Maintenance: An Inquiry into Values. New York: Morrow.

Pollan, Michael. 2008. In Defense of Food: An Eater's Manifesto. New York: Penguin.

----. 2007. The Omnivore's Dilemma: A Natural History of Four Meals. New York: Penguin.

Ritzer, George. 2012. 7th ed. The McDonaldization of Society. Los Angeles: Pine Forge.

Rodgers, Bill (with Matthew Shepatin). 2013. Marathon Man: My 26.2 Mile Journey from Unknown Grad Student to the Top of the Running World. New York: Thomas Dunne.

Roll, Rich. 2012. Finding Ultra: Rejecting Middle Age, Becoming One of the World's Fittest Men and Discovering Myself. New York: Crown.

Schlosser, Eric. 2012. Fast Food Nation: The Dark Side of the All-American Meal. New York: Mariner.

Shapiro, James E. 1982. Meditations from the Breakdown Lane: Running Across America. New York: Random House.

Sheehan, George. 1978. Running and Being: The Total Experience. New York: Random House.

Switzer, Katherine. 2007. Marathon Women: Running the Race to Revolutionize Women's Sports. New York: Carroll and Graf.

Ulrich, Marshall. 2011. Running on Empty: An Ultramarathoner's Story of Love, Loss, and a Record-Setting Run Across America. New York: Avery.

VanOrden, Tim. 2013. www.runningraw.com. 